\title{
Correction: Molecular evolution of the keratin associated protein gene family in mammals, role in the evolution of mammalian hair Dong-Dong $\mathrm{Wu}^{1,3}$, David $\mathrm{M}$ Irwin $^{4}$ and Ya-Ping Zhang*1,2
}

Address: ${ }^{1}$ State Key Laboratory of Genetic Resources and Evolution, Kunming Institute of Zoology, Chinese Academy of Sciences, Kunming, PR China, ${ }^{2}$ Laboratory for Conservation and Utilization of Bio-resource, Yunnan University, Kunming 650091, PR China, ${ }^{3} \mathrm{Graduate}$ School of the Chinese Academy of Sciences, Beijing, PR China and ${ }^{4}$ Department of Laboratory Medicine and Pathobiology and the Banting and Best Diabetes Centre, University of Toronto, Ontario, Canada

Email: Dong-Dong Wu - dongdongw86@yahoo.com.cn; David M Irwin - david.irwin@utoronto.ca; Ya-Ping Zhang* - zhangyp@mail.kiz.ac.cn

* Corresponding author

Published: 25 August 2009

BMC Evolutionary Biology 2009, 9:213 doi:10.1186/1471-2148-9-213

This article is available from: http://www.biomedcentral.com/I47I-2/48/9/2I3

(c) 2009 Wu et al; licensee BioMed Central Ltd.

This is an Open Access article distributed under the terms of the Creative Commons Attribution License (http://creativecommons.org/licenses/by/2.0), which permits unrestricted use, distribution, and reproduction in any medium, provided the original work is properly cited.
Received: 20 August 2009

Accepted: 25 August 2009

\section{Correction to Wu DD, Irwin DM, Zhang YP: Molecular evolution of the keratin associated protein gene family in mammals, role in the evolution of mammalian hair. BMC Evol Biol 2008, 8:24l.}

Abstract

\section{Correction}

In the publication of our work [1], in the table two: Amino acid composition of KRTAPs subfamily genes in mammals, the subfamily 30 should be deleted, and the subfamily 34 should be corrected as 30,35 should be corrected as 34 , and 36 should be corrected as 35 . Here, we provide a table 1 , which is a corrected version of table two. In the additional file 1, mouse gene repertoire in the table S1, at the line 42 , the KRTAP34p1 should be corrected as KRTAP30p1; from the line 177 to 189 , the chromosomes should be chr1. We provide a correction of additional file 1 . We regret any inconvenience caused to researchers. 
Table I: Amino acid composition of KRTAPs subfamily genes in mammals.

\begin{tabular}{|c|c|c|c|c|c|c|c|c|c|}
\hline HS-KRTAP & subfamily & C & $\mathrm{G}$ & $\mathrm{L}$ & $\mathrm{P}$ & $\mathrm{Q}$ & $S$ & $\mathrm{~T}$ & $Y$ \\
\hline & 1 & 26.57 & 10.04 & 1.67 & 9.22 & 6.84 & 15.55 & 8.04 & 1.88 \\
\hline & 2 & 29.1 & 4.42 & 1.44 & 14.4 & 6.03 & 10.33 & 9.25 & 0.56 \\
\hline & 3 & 19.93 & 4.72 & 8.01 & 15.6 & 2.9 & 8.53 & 10.84 & 1.53 \\
\hline & 4 & 37.37 & 2.98 & I & 10.57 & 5.47 & 16.21 & 7.91 & 0.51 \\
\hline & 5 & 35.86 & 23.67 & 0.1 & 5.01 & 3.39 & 19.25 & 0.65 & 0.27 \\
\hline & 9 & 35.26 & 2.65 & 1.02 & 11.04 & 7.17 & 12.74 & 13.95 & 1.32 \\
\hline & 10 & 27.61 & 2.55 & 3.34 & 13 & 6.1 & 18.76 & 4.62 & 0.52 \\
\hline & II & 13.1 & 8.08 & 4.08 & 8.24 & 7.45 & 14.75 & 12.16 & 2.43 \\
\hline & 12 & 22.86 & 2.57 & 2.17 & $|3.8|$ & 6.18 & 21.12 & 4.02 & 1.33 \\
\hline & 13 & 11.47 & 10.61 & 5.73 & 7.41 & 4.17 & 21.31 & 5.88 & 7.49 \\
\hline & 17 & 36.06 & 31.44 & 0.26 & 4.49 & 4.23 & 9.91 & 3.17 & 0 \\
\hline & 24 & 9.77 & 5.05 & 7.45 & 9.38 & 3.99 & 17.55 & 7.31 & 7.18 \\
\hline & 25 & 7 & 5.07 & 5.56 & 8.21 & 6.28 & 19.08 & 3.86 & 6.28 \\
\hline & 26 & 11.3 & 9.04 & 8.47 & 11.45 & 4.01 & 18.08 & 5.14 & 3.24 \\
\hline & 27 & 8.7I & 4.07 & 6.59 & 7.81 & 7.81 & 18.06 & 7.73 & 1.38 \\
\hline & 28 & 39.54 & 33.66 & 0.01 & 1.6 & 3.93 & 5.8 & 2.69 & 1.02 \\
\hline & 29 & 16.27 & 6.01 & 3.34 & 11.42 & 8.33 & 16.7 & 7.84 & 2.39 \\
\hline & 30 & 50.73 & 4.65 & 0.17 & 9.54 & 11.11 & 4.42 & 8.55 & 0.23 \\
\hline & 31 & 26.53 & 1.02 & 3.06 & 11.9 & 4.76 & 15.08 & 10.66 & 0.11 \\
\hline & 32 & 38.72 & 3.4 & 1.91 & 16.17 & 4.26 & 10 & 8.94 & 0.21 \\
\hline & 33 & 32.18 & 5.42 & 2.65 & 15.29 & 1.52 & 9.17 & 3.19 & 0.11 \\
\hline & 34 & 9.19 & 8.38 & 4.32 & 11.08 & 4.05 & 21.62 & 8.11 & 5.68 \\
\hline & 35 & 10.34 & 4.6 & 8.05 & 11.49 & 6.9 & 20.69 & 6.9 & 1.15 \\
\hline \multirow[t]{6}{*}{ HGT-KRTAP } & 6 & $13.6 \mid$ & 40.26 & 4.87 & 0.19 & 0.05 & 7.59 & 0.29 & 22.87 \\
\hline & 7 & 8.81 & 19.16 & 4.79 & 7.28 & 0.19 & 11.49 & 6.13 & 12.26 \\
\hline & 8 & 5.72 & 23.97 & 3.94 & 7.16 & 0 & 8.59 & 2.15 & 20.04 \\
\hline & 19 & 6.07 & 36.52 & 4.22 & 1.38 & 0.33 & 10.8 & 0.33 & 19.96 \\
\hline & 20 & 13.9 & 37.61 & 4.61 & 1.73 & 0.26 & 5.72 & 0.23 & 24.2 \\
\hline & 21 & 17.2 & 36.82 & 0.93 & 1.03 & 0.24 & 12.6 & 0.87 & 20.98 \\
\hline
\end{tabular}

The average amino acid content (\%) of high cysteine (HS) and high glycine/tyrosine (HGT) KRTAP subfamily genes is shown. C (cysteine), G (glycine), L (leucine),

$\mathrm{P}$ (proine), Q (glutamine), S (serine), T (threonine) and $\mathrm{Y}$ (tyrosine) are single letter codes for amino acids that are abundant in some KRTAP proteins.

\section{Additional material}

\section{Additional file 1}

Table S1 - KRTAP genes in the human, chimpanzee, rhesus macaque, dog, mouse, rat, opossum, and platypus genomes.

Click here for file

[http://www.biomedcentral.com/content/supplementary/1471-

2148-9-213-S1.xls]

\section{References}

I. Wu DD, Irwin DM, Zhang YP: Molecular evolution of the keratin associated protein gene family in mammals, role in the evolution of mammalian hair. BMC Evol Biol 2008, 8:24I.
Publish with Bio Med Central and every scientist can read your work free of charge

"BioMed Central will be the most significant development for disseminating the results of biomedical research in our lifetime. "

Sir Paul Nurse, Cancer Research UK

Your research papers will be:

- available free of charge to the entire biomedical community

- peer reviewed and published immediately upon acceptance

- cited in PubMed and archived on PubMed Central

- yours - you keep the copyright
BioMedcentral 